\title{
Re-reading remittances through solidarity: Mexican hometown associations in New York City
}

\author{
Araby Smyth \\ University of Kentucky, Geography Department, 817 Patterson Office Tower, Lexington, KY 40506, United States
}

\section{A R T I C L E I N F O}

\section{Keywords:}

Remittances

Solidarity economy

Hometown associations

Development

Diverse economies

Mexico

\begin{abstract}
A B S T R A C T
This paper analyzes how Mexican hometown associations in New York City practice solidarity so that they might best meet the needs of the transnational communities that they serve. Commonly formed by immigrants in the United States, hometown associations are organizations which send money collectively to their home countries, supporting public infrastructure and community projects. Scholars have debated both the merits of remittance programs that channel migrant funds as economic development and the agency of immigrant economies in neoliberal development structures. Through primary data collected from interviews in New York City, I review the frustrations that hometown associations have with one such program: Mexico's programa tres por uno para migrantes. Concurrently, I examine how the same hometown associations engage ethical economic practices of collective remittance sending and community service provision in New York City. Drawing on feminist literature on diverse economies, I argue that the solidarity work of hometown associations disrupts the dominant remittance as development discourse. Migrants are not content to participate in tres por uno and through practicing solidarity they distance themselves from this neoliberal policy.
\end{abstract}

\section{The work of Mexican hometown associations}

In the fall of 2013 a small group in New York City (NYC) met to discuss forming a hometown association (HTA) so that they could raise funds to support their town in Central Mexico. After the meeting, they gathered approximately a dozen other people from their hometown living in NYC, partnered with 10 others in their hometown, and formed a HTA. Together they polled their broader communities in NYC and in Mexico and discussed what project would benefit the hometown. Some members wanted to build a school or repave roads, but eventually they collectively decided to rebuild the town cemetery. The cemetery was over 100 years old, had few spaces left for burials, and there was serious soil erosion that was disturbing and destroying burial plots.

The core dozen members in NYC registered the HTA and cemetery project with the Mexican Consulate in order to be eligible for matching funds from the programa tres por uno para migrantes (three for one program for migrants, hereafter referred to as $3 \times 1$ ). They began collecting $\$ 50$ donations from the approximately 800 people from their hometown who live in the NYC area. The money was deposited in a bank account in the capital of the hometown's municipio (municipality) ${ }^{1}$ and, through $3 \times 1$, was matched by the three levels of the Mexican government: federal, state, and municipal. Not including matching funds, the members in NYC raised between $\$ 10$ and 11,000 USD. With this money, the cemetery project was undertaken in the last four months of 2014, one year after the group first met.

At first glance this is a success story: migrants from Mexico collaborate and make a much-needed improvement to the infrastructure in their hometown, and receive significant sponsorship from the Mexican government. However, the reality is more complex. Based on my research of HTAs in NYC, I argue that migrants are not content to participate in remittance channeling policies, like $3 \times 1$ that represent an attempt on behalf of the government to share the burden of infrastructure maintenance and development with migrants. Mexican migrants build volunteer networks in NYC that help their hometown out of a sense of shared economic responsibility, and in doing so engage in democratic decision-making and mutual support. It is for these two reasons that I consider the HTAs' practices of cooperation and concern for the well-being of people in NYC and Mexico as a form of solidarity. By studying how HTAs practice solidarity we learn how they distance themselves from the neoliberal remittance policy regime that pressures migrants to send remittances to rural municipalities in Mexico.

HTAs struggle to maintain autonomy from $3 \times 1$ as they work for the mutual benefit of their members, which raises the question that guided this research: how do immigrants create and navigate

\footnotetext{
E-mail address: arabysmyth@uky.edu.

${ }^{1}$ The state of Mexico and federal government has smaller administrative divisions beginning with states and then municipalities. Each municipality is led by the elected presidente municipal (municipal president).
} 
transnational economic practices based on solidarity? Empirically, I draw on research with Mexican HTAs in the United States (US), and situate my work in feminist literature on diverse economies and solidarity. This framework allows for an analysis of how HTAs serve the needs of transnational communities through the lens of ethical economic practices. While HTAs engage with $3 \times 1$ they refuse to be controlled by its governance. Considering the missions of HTAs as solidarity practice disrupts the dominant discourse of remittance as development, and stresses the economy as a space of difference where migrants prioritize the well-being of community.

In section two I review the literatures that contribute to my analysis of HTAs in NYC: remittances in development studies, solidarity and diverse economies, and literature that contextualizes the work that HTAs do for immigrant population living in the US. The third section details my methods for researching Mexican HTAs in NYC. In the fourth section I summarize how HTAs work with the Mexican government through $3 \times 1$ and describe the problems and concerns that arise in this relationship. The ways that HTAs practice solidarity is the basis for the fifth section of the paper. Finally, I conclude that not only is the Solidarity Economy literature helpful for understanding HTAs, but that the solidarity practices of HTAs also contribute to a deeper analysis of the Solidarity Economy.

\section{Remittances and solidarity}

\subsection{Channeling remittances via neoliberal policy}

HTAs are a part of a vast remittance network, involving migrants across the globe. Remittances are money or goods sent by migrants to their families and friends in their place of origin. Worldwide, the value of migrant remittances climbed from $\$ 31.1$ billion USD in 1990 to almost $\$ 76.8$ billion USD in 2000 , and is estimated currently to be around \$441 billion USD (de Haas, 2010; Ratha et al., 2016). Remittances to Mexico from the US doubled from less than $\$ 5$ billion USD in 1995 to approximately $\$ 10$ billion USD in 2002 (FitzGerald, 2009). Since 2010 remittances have competed with oil exports as the largest source of revenue for Mexico (Aparicio and Meseguer, 2012). In 2016 remittances to Mexico reached almost \$27 billion USD (Banco de México, 2017; The Associated Press, 2017).

Scholars began to connect remittances to economic development in the 1980s and 1990s (Russell, 1986; Durand et al., 1996; Massey and Parrado, 1994) and international organizations such as the World Bank and United Nations argued that remittances should be deliberately harnessed for economic development in migrant sending communities (Bakker, 2015; Glick Schiller and Faist, 2009). Remittances were heralded as a significant, consistent, and reliable source of capital flow to developing countries (Ratha, 2003). Connecting remittances to poverty reduction led to considerations of how to increase impact and to policies such as incentive programs for capturing and leveraging remittances (Adams and Page, 2005; Brown, 2006; Orozco, 2002; Ratha, 2005, 2007). The Mexican government launched its own remittance loan and matching program: programa tres por uno para migrantes $(3 \times 1)$ in 2002 , to fund infrastructure development in migrant sending communities.

The rise of state-sponsored programs that seek to channel remittances as a form of development has sparked debate (see Gamlen, 2014). On the one hand, proponents of remittances as development stress the importance of leveraging remittances in certain kinds of investment. For instance, remittances are commonly exchanged between individuals and family members as a source of household income to be spent on education, health, and entrepreneurship (Ratha, 2006). Household remittances are known to reduce poverty and generate positive multiplier effects (FitzGerald, 2009), but there is a push to channel them through "productive investments" such as infrastructure, business, or agriculture (Zarate-Hoyos, 2004). $3 \times 1$ encourages these types of investments and Mexican HTAs are frequently analyzed by policy experts in terms of "development potential" (Orozco, 2006; Orozco and Rouse, 2007).

Others, however, see programs such as $3 \times 1$ as contributing to inequality, using remittances in place of funding from the government to pay for public works, and as contradictory. Critics of $3 \times 1$ argue that it is unfair to expect migrants to consistently send remittances to fund infrastructure projects (Delgado Wise and Eduardo Guarnizo, 2007) and that putting the responsibility of development on migrants and their sending communities is simply a neoliberal response to the withdrawal of state funding from local development and social support programs (Faist, 2008; Gamlen, 2014; Zapata, 2013). Remittances have been documented as having both negative and positive impacts on migrant sending communities (Jones, 1992, 1998; Kanaiaupuni and Donato, 1999). Datta et al. (2007) point out that programs such as $3 \times 1$ fail to address structural inequalities such as push factors that propel often risky cross-border migration or the low wages and exclusion in the receiving countries of the Global North.

This paper contributes to discourse on remittances and development, arguing that HTAs are not simply offshoots of state-sponsored remittance programs. They participate in $3 \times 1$ because it multiplies their efforts by matching the funds that they raise. However, they view themselves and the broader communities in NYC and Mexico that they represent, and not the government, as the architects of development in their hometowns.

\subsection{Solidarity and diverse economies}

In order to analyze the way that HTAs work in the US and in Mexico and how they might be creating alternatives to, or within, the more generally neoliberal development framework described above, I turn to the Solidarity Economy literature that intersects with the Diverse Economies literature and Community Economies methodology spearheaded by JK Gibson-Graham (1996, 2006, 2008). Scholars have developed rich typologies of the Diverse Economy - three are particularly relevant to analyzing how HTAs operate: economies of generosity, the global household, and the Solidarity Economy. ${ }^{2}$ Economies of generosity are a mode of production based on volunteer networks that focus on mutual aid goals (Community Economies Collective, 2001). Composed of family members and friends who live in different parts of the world, the global household is a site of production that makes significant economic contributions (Safri and Graham, 2010). The Solidarity Economy entails economic practices and a social movement, and it consists of organizations and institutions that prize social solidarity, community development, cooperation, ecological sustainability, and democratic self-management (Borowiak, 2014). All three include formalized practices such as investments and savings, dedication to workplace democracy and local community support as well as informal practices like networks of family and friends, community groups, and favors (Pavlovskaya, 2013).

The theoretical framework of the Solidarity Economy challenges the framing of remittances as development described in the previous section. The Solidarity Economy is "a set of practices and theories promoting democratic, just, and sustainable development" (Loh and Shear, 2015, p. 245). Practices of solidarity include "relationships of mutual support" and "shared responsibility and directly democratic decisionmaking" (Miller, 2010, p. 25). Solidarity economy literature offers an alternative development framework that is not universal, centralized, and hierarchical, but allows for hybridity and operates on principles of pluralism, particularity, diversity, decentralization, and localization (Borowiak, 2014; Kawano, 2010). Solidarity practices center on "altruism, reciprocity, cooperation" and go against neoliberal policy

\footnotetext{
${ }^{2}$ There are also exploitative economies within the diverse economy, but those I emphasize are forward looking and progressive, based on cooperation and solidarity instead of exploitation, profit maximization, and competition.
} 
(Kawano, 2010, pp. 14-15). Remittance sending is a complex transnational social transaction that takes place for a variety of reasons. I use this literature to analyze the practices of Mexican HTAs beyond the money they transfer and their participation in $3 \times 1$ because it encourages the examination of politics behind the spaces and subjectivities that immigrants create for their economic projects. Moreover, it critiques the conceptualization of remittance based development as a process that is "unequal and exclusionary" (Santos and RodríguezGaravito, 2007, p. xxxv) within a narrowly-defined, neoliberal framework that demands that communities either conform or be deemed failures (Gibson-Graham, 2006).

\subsection{More than remittances}

My findings support research about the work that HTAs do beyond sending remittances. The approximately 2478 HTAs in the US (and roughly 200 more worldwide) represent localities in most if not all of the states in Mexico, and they are more than economic vehicles that send remittances ("Directorio de Organizaciones y Clubs de Oriundos," 2016). They have roots in the mutual aid associations of Mexican immigrants in the southwest at the beginning of the 20th century and have, by now, cemented their place as significant institutions that simultaneously undertake projects back home and build support structures for immigrant communities in the US (FitzGerald, 2009; Fox, 2012; Gamio, 1930). HTAs serve as an entry point into US civil society and provide "safe spaces" for members, including unauthorized immigrants (Escala Rabadán et al., 2006; Fox and Bada, 2011; Ramakrishnan and Viramontes, 2010; Waldinger et al., 2008; Zabin and Escala Rabadán, 2002). HTAs in Chicago took on leadership roles in planning protests against the Border Protection, Antiterrorism and Illegal Immigration Control Act in 2006 (Vonderlack-Navarro and Sites, 2015). HTAs in NYC create distinct Mexican spaces in the city through the activities they organize and the services they provide. These spaces connect people who share regional identity and provide them with support (Hum, 2014; Smith, 2001). In section five I will describe how HTAs organize and participate in community development in NYC by hosting social events that celebrate the culture of their hometowns in Mexico and provide services to the Mexican immigrant community in NYC. I analyze this work that HTAs do in NYC as solidarity practices and argue that it is in this building of networks of care that migrants distance themselves from neoliberal policies.

I draw upon and combine these three literatures in my analysis about the frustrations that HTAs have with $3 \times 1$ and their concerns about the precarity of their members' lives in NYC. I argue that one of the ways that HTAs manage these tensions is by practicing solidarity. Difficult economic conditions led to members' decisions to emigrate from Mexico and they want to give back to their hometowns, yet they are angry that so much of the responsibility for funding development has been placed on them. At the same time, they feel a responsibility to help members negotiate life in NYC. Solidarity is a way that HTAs exhibit different values from and distance themselves from neoliberal policy.

\section{Methods for researching hometown associations}

This article draws on my analysis of primary data collected during the winter and spring of 2014-15. During this research, I conducted semi-structured interviews with representatives of a dozen organizations that represent and engage the Mexican immigrant community in all five boroughs of NYC. Among these organizations, I interviewed the leaders of five HTAs that were between one and 15 years old. Most of the HTAs had participated in $3 \times 1$. In addition, I interviewed employees of the Mexican Consulate who work with these organizations. Further, I spent time as a participant observer in neighborhoods in NYC where HTAs reported significant membership: the Arthur Avenue section of the Bronx, Elmhurst and Corona in Queens, and Bushwick and
Sunset Park, Brooklyn. My fieldwork included documenting the presence of Mexican-identified businesses to gain first-hand knowledge about the places that interview participants spoke about, and to provide context to their narratives. I also reviewed and analyzed the content of websites of key ministries of the Mexican government, Mexican immigrant organizations in NYC, and the Facebook pages and groups of HTAs. I used grounded theory as my primary methodology for identifying and organizing the themes across different text sources such as websites and notes from my interviews and neighborhood fieldwork (Charmaz, 2014; Glaser and Strauss, 1967).

Where the interviews took place and how they were documented was carefully considered (Elwood and Martin, 2000). When an organization had an office, the interview took place in that space. When they did not, we met at coffee shops, churches, and public places of the participants' choosing, a process that took me to all the neighborhoods mentioned above, and beyond. I chose not to record the interviews and instead took notes, attempting to create a more relaxed environment between myself and the participant so that their responses might be less guarded (Cloke et al., 2004).

Throughout all the interviews I was cognizant of my position as an outsider and thus worked hard to develop a rapport with my research participants and establish positional spaces of betweenness (Mullings, 1999; Nast, 1994). This included explaining my research project throughout our time together, and giving participants several opportunities to ask me questions about myself and the project. For example, I was often asked how I came to know about HTAs and what I thought of US immigration reform. I responded by telling participants about my educational background, my work as an immigrants' rights activist, and my position in favor of radical immigration reform in the US. As an activist, I had friendships that helped me to establish relationships with key figures in the Mexican immigrant community in NYC, which in turn connected me to HTA leadership.

My interviews were limited in focus and I only asked participants about the history of the organization, how they identified its mission, as well as what motivated and challenged the organization's work. While HTAs are contested spaces where the class, gender, and immigration status of HTA leaders and membership are important considerations (Alarcón and Escala Rabadán, 2007; Smith and Bakker, 2007; Smith, 2006; Waldinger et al., 2008) and they informed my understanding of HTAs, these topics were not included in the interview questions. I did not explicitly ask participants to give details about the demographics of members and I never asked questions about anyone's personal lives or immigration status.

\section{HTA projects in Mexican hometowns and problems with $3 \times 1$}

I began with the story of the HTA that re-built a cemetery in Central Mexico and I return to it now as an illustration of how HTAs work with $3 \times 1$. When members of this HTA first came together in NYC in 2013 they began a lengthy and complicated affair of collaborating with people in their hometown and the government in order to rebuild the cemetery. $3 \times 1$ includes representatives at the state and local level as well as three ministries of the Mexican federal government: the Mexican Consulates in the US, the Instituto de los Mexicanos en el Exterior (Institute of Mexicans Abroad or IME), and the Secretaría de Desarrollo Social (Department of Social Development or SEDESOL) (for more on the history of $3 \times 1$, its multi-scalar nature, and how it works with HTAs that represent various parts of Mexico see Aparicio and Meseguer, 2012; Bada, 2016; FitzGerald, 2009; Fox and Bada, 2008; Iskander, 2010; Lopez, 2015).

SEDESOL presents a mission of strengthening transnational ties through collective projects that benefit entire communities, particularly among underserved and vulnerable populations. In addition to the cemetery project, 2058 projects were carried out by HTAs and $3 \times 1$ during 2014. Most of the projects (75\%) were dedicated to improving infrastructure in Mexico. Ten percent were investments towards small 
businesses, and $15 \%$ are categorized as "other" (SEDESOL: Secretaría de Desarrollo Social, 2015). In New York, New Jersey, and Connecticut, the projects that HTAs completed in 2014-15 included but were not limited to the construction of a school, a multi-use space, a potable water tank, and a civic plaza, the paving and remodeling of a road and a zócalo (central square or park), equipping a public school with computers; investing in small businesses like agriculture, stores, and a green hotel for ecotourism; and projects to strengthen the work of social service organizations (SEDESOL: Secretaría de Desarrollo Social, 2015). The rest of this section will detail the relationship that HTAs have with the government through a description of how they initiate a project with $3 \times 1$ and then how they negotiate their own decisions and desires with state actors.

\subsection{Re-building a cemetery}

At the time of my research there were 50 Mexican Consulates in the US and three representatives of SEDESOL based at Consulates in Los Angeles, Chicago, and NYC. The representative in NYC works with migrants and HTAs in each of the states along the East Coast of the US from Maine to Florida, as well as parts of Eastern Canada. Over a period of four months (late 2013 through early 2014) members of the cemetery HTA initiated a series of meetings with each other, as well as representatives from the Mexican Consulate in NYC, and a politician from their home state who visited NYC. The HTA consulted with government representatives on how to best propose, fund, and execute their project. Meetings between HTA members took place in person in NYC as well as virtually on Facebook where ideas for what kind of project to fund were debated. First, the Consulate verified the HTA and its committee in NYC and Mexico, then issued a certificate of recognition, a toma de nota, to the HTA's leadership. The toma de nota stated that SEDESOL officially recognized the HTA, and it included the HTA's mission, where it originates in the US, and to which state and municipality it was connected in Mexico. Next, the HTA established a bank account in their municipality and received approval for their project from SEDESOL. They did this by presenting the toma de nota to the presidente municipal, the Municipal President of the local government. Finally, they consulted with the Municipal President and the SEDESOL representative at the Consulate about how to best propose the cemetery project so that it would be approved when under review by SEDESOL in Mexico City.

Once their status as an organization was recognized by the government and approval for the cemetery project was granted, the HTA began sending money to the bank account in their municipality. The funds were matched by the federal, state, and municipal levels of the Mexican government. The work on the cemetery was carried out from September to December 2014. Equipment was brought to the town and supplies were purchased so that a new foundation and wall could be laid around the perimeter of the cemetery. So that the project would economically benefit the town, the HTA stipulated that whenever possible, local people should be hired as laborers and that materials were to be bought or rented in the town. The HTA exercised collective leadership and decision-making in that the supervision of the project was shared by HTA leadership in NYC and in the hometown as well as by the municipal government. As the cemetery project was confirmed and then underway, photos, videos, and updates were posted to Facebook so that the broader membership who donated to the project could follow its progress.

The language and practice of dominant development discourse is often geared at alleviating poverty and it is popular to direct aid towards improving education or health prospects. However, these kinds of investments are not always what those on the receiving end of aid money or infrastructure projects desire, and projects often have unintended and even negative consequences (Escobar, 2008; Ferguson, 1994). In the case of this HTA, they did not fund a typical development project but instead invested in a burial site. This connects with other geographic work about migrants who chose to invest remittances in the creation of and maintenance of memorial spaces for the dead (Mercer et al., 2008). Initially, HTA members in NYC wanted to build a school. They were motivated by a desire to bring long-term opportunities to their hometown and believed that strengthening education would improve people's chances at getting a better job, which in turn would help them support their families and bring further economic development to their hometown. In this instance, people in the hometown disagreed with the HTA members in NYC who wanted to collect funds in support of a school or education project. From the vantage point of people living in the hometown, the devastation of the local cemetery was a more serious problem. The cemetery was over 100 years old and was deteriorating from soil erosion that disturbed burial plots.

HTA organizing spans the distance between NYC and Mexico, taking place in person and virtually so that different members of both communities could voice their opinions about what kind of project should be funded in the hometown. HTA members in NYC discussed the importance of recognizing that the people living in the hometown possessed the knowledge to best determine which project would benefit the town. Eventually, through collective online discussions, most members, both in NYC and in the hometown, shared the opinion that the reconstruction of the cemetery should be funded. The members in NYC believed that the cemetery was more beneficial to the town because it was the project that the people in the hometown wanted.

Building on these details of the process for HTAs working with $3 \times 1$ and how they engage with members on both sides of the border, in the following sections, I take a step away from this particular case and discuss the concerns that HTAs have about working with $3 \times 1$ more generally. Not only is funding a project a complex bureaucratic process, but it sometimes generates disappointment, suspicion, and conflict between the actors.

\subsection{Concerns about control and transparency}

Several HTA leaders described that they felt used by the Mexican government for their continuous stream of remittances. Their stories exemplify how HTAs are not simply reproducing $3 \times 1$ 's development model. These feelings materialized in moments such as when a Municipal President initially asked for one HTA's toma de nota so that he could receive state and federal funds to initiate construction projects. Other HTA leaders described how municipal presidents came to NYC to woo migrants into forming committees and then hoped the HTA would relinquish the toma de nota so that the local government might receive state and federal funds. Migrants say that they are told that if they do this they will be helping their hometown and that the municipal government apparatus will take care of it, and give them credit.

However, the HTA leaders I spoke to see this as an attempt to cut them out of the decision-making process - a process that they carefully and collectively organize, as described in the previous section. Leaders said that when local government officials plan projects without the input of migrants and the local community, it is less likely to reflect what the people living in the hometown want - and that credit may not be given to the migrants for their financial contribution. With regards to the struggle over who makes decisions about what towns need, one participant wondered if it is even possible for migrants to ever express and have their concerns heard on a level playing field with the government because it is more powerful. HTA leaders consistently asserted a desire that the projects serve the needs of the people in the hometown. In addition, many, including the HTA that reconstructed the cemetery, insisted that whenever possible all the laborers and materials for the project come from the hometown so that income would be generated locally.

Another major concern expressed by the participants interviewed, was the transparency and accountability of the local municipal government regarding the handling of $3 \times 1$ funds. Interview participants indicated wariness about sharing a bank account with the government. Most said that they had heard stories about HTA money being 
Table 1

HTA practices of solidarity.

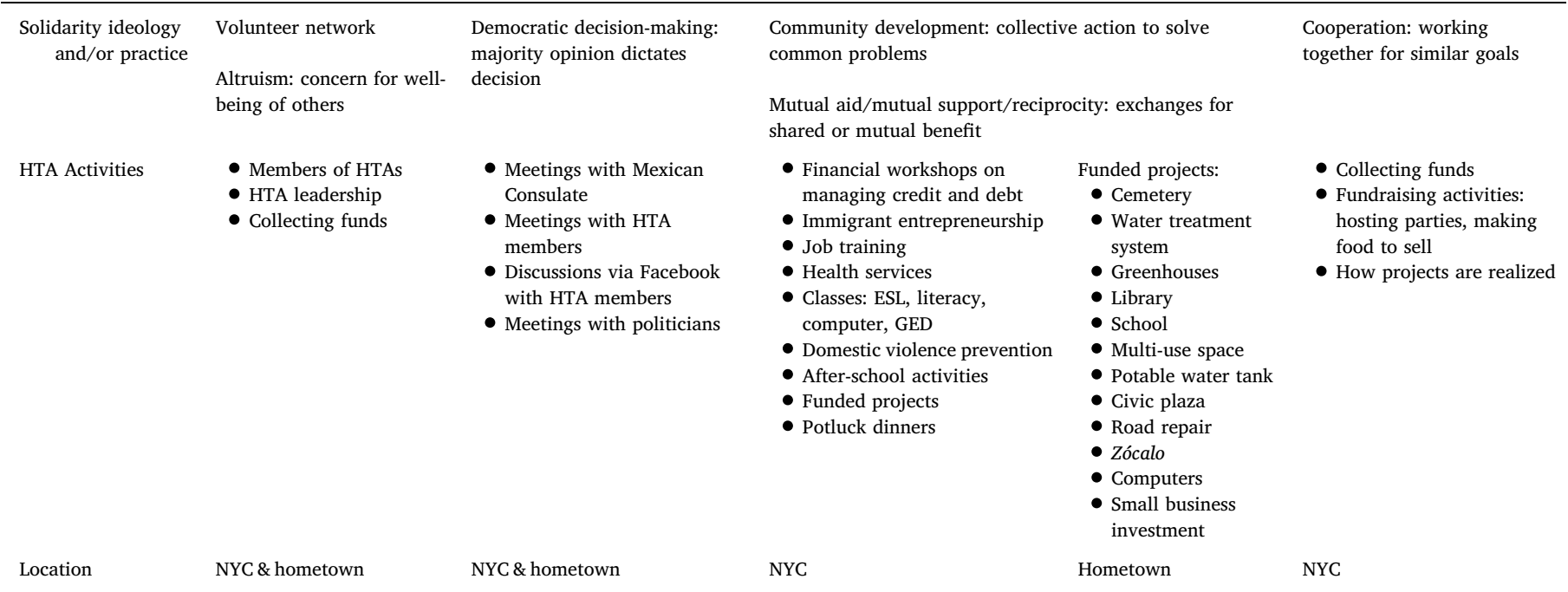

misappropriated, and in one instance it was asserted that as much as 16 percent of an HTA's funds may have been mismanaged by local government actors. HTA leaders were concerned because they said it is often leaders at the municipal government level who are primarily responsible for managing the bank account and distributing funds as a project is completed.

The HTA leadership interviewed for this project wanted to distance themselves from financial mismanagement and corruption. By doing so, they practiced a different kind of leadership and decision-making. Group forums on Facebook were an important communication tool that aided both in transparency and alleviating the physical distance between group members. They posted updates and different points of view regarding decisions, a project's progress, funding, and more on Facebook. When I asked about the possibility of solutions to issues of transparency, like working with state or federal politicians in order to put pressure on the local government, the common response I heard was that HTA leaders did not want to form additional alliances with politicians beyond $3 \times 1$ even if it meant solving their immediate problems. HTA leaders acknowledged difference in the various state actors present in $3 \times 1$ but they also expressed wanting to distance themselves from politicians in general. The lack of transparency reflects negatively on the HTA and does not represent the values that they are cultivating such as democratic decision-making through a network of volunteer members. One leader I spoke with reported that it was very important to him that HTA leadership not be likened to politicians in Mexico, specifically the kinds of politicians he viewed as responsible for corrupting local economies and depleting municipalities and small towns of resources. This is one of the reasons, he said, that he and many others have emigrated. Even though collaborating with $3 \times 1$ is difficult, it is beneficial because as one leader begrudgingly said "but how else can we make $\$ 3000$ into $\$ 12,000$ ?" HTAs balance feelings of wariness and resentment towards state actors with their desire to realize projects that benefit their hometowns.

HTA members have complex points-of-view about how they work closely with different levels of the Mexican government (Bakker, 2007). I interpret HTA leaders' frustration with $3 \times 1$ and their wish to be less entangled with it in two ways. First, HTA leaders feel that some politicians are corrupt and partially responsible for the neglect of their hometowns. From the perspective of HTA members, funding development projects is a direct solution to governmental neglect. While they work with the government to fund and coordinate the completion of these projects, they are skeptical of government input into the decisionmaking process and the management of projects. Second, HTA leaders described a struggle between themselves and local politicians to maintain control over their projects. At the root of this control is who gets credit for completion of the project: the local government or the members of the HTA? Even if an HTA strives to be disconnected from politicians and party platforms, they felt that a completed project will always show politicians in a favorable light because it is done in cooperation with funds from the federal, state, and municipal governments. Other research points to HTAs facing similar challenges such as contradictions and political conflicts with local and state authorities (Bakker, 2007; Delgado Wise, 2006; García Zamora, 2007).

Theorizing about the solidarity economy stresses that its practices do not exist in isolation from or opposition to state actors or neoliberal policy. Solidarity work allows for hybridity and pluralism (Borowiak, 2014; Kawano, 2010). One can see this in the tensions over transparency and control. HTA leaders said that their members wanted to do projects that provide the hometown with long-term benefits. It is important that projects reflect the hometown's desires and that it be carried out on their terms. They realized that consulting with the government is a necessity, but they were skeptical of the municipal government's opinion on what is needed at the local level. HTA leaders valued a democratic decision-making process that worked by first discussing and reaching consensus on potential projects with residents in their hometown and then involving local municipal government actors as a second opinion. Democratic decision-making processes and other non-economic solidarity practices that HTAs in NYC enlist will be reviewed in the next section.

\section{Practicing solidarity: HTA activities in NYC}

HTAs do more than send remittances. In addition to funding hometown projects, HTAs mobilize volunteer networks and provide support to the Mexican immigrant community in NYC. They act out of a desire to create mutual aid and solidarity in their pursuit of solving common problems faced by Mexican immigrants in NYC. This section will analyze the community support that HTAs provide in NYC as practices of solidarity (see Table 1). They create a visible cultural presence in NYC by sponsoring soccer teams, hosting potlucks, and they offer services such as English-language and General Education Development $^{3}$ classes, computer training, and clothing drives. By placing these activities alongside HTA utilization of democratic decision-

\footnotetext{
${ }^{3}$ General Education Development or GED is a series of tests that upon completion, certify the equivalency of a high-school diploma.
} 
making and prioritization of hometown desires, I argue that their solidarity practices challenge assumptions that they are easily commodified or willing participants in neoliberal policy.

\subsection{Community support and hometown pride}

Every weekend the soccer pitches at Flushing Meadows-Corona Park in Queens and the Red Hook Ball Fields in Brooklyn fill up with players from around the world. Considered a huge social event in the Latino community, whole families come out to play in soccer games all day. Soccer teams are important gateways to community organizing in Latino communities in the US and they are a major part of how HTAs attract new members (Nelson, 2017; Price and Whitworth, 2004). Soccer teams and leagues are often established early on, before any other organizational coordination begins. Teams incorporate the placenames of hometowns or states into their identities to attract players and fans from the same region, and to announce the hometown's presence on the field, and in the city. One participant reported that having a soccer team is important because it captures the interest of younger members. The young men come to the organization for the soccer, and when they are on the team they connect with other men from the same region, discuss issues that concern them, and learn about how an HTA is forming or is already in existence. They are invited to participate in the HTA's activities, offered services from the HTA, and motivated by the HTA to act themselves.

In addition to soccer, HTAs bring members together in frequent potluck dinners where members gather with their families and enjoy prepared dishes in the style of their hometown (Gutiérrez and Remington, 2017; Rivera, 2003). This is an important cultural activity that brings people from the same region together and it provides an opportunity for members to teach younger generations that are growing up in the US about the hometown. Dinners are a venue for organizing around and collecting donations not just for $3 \times 1$ projects, but also for local projects such as the donation of clothes, food, and books. One HTA in Queens supports day-laborers in Long Island from the same region in Mexico because members of the HTA know that day-laborers often experience low and irregular pay. HTAs also coordinate with other actors like the Mexican Consulate to alert immigrants on Long Island about services in the city. Another HTA collected and distributed children's books containing content about their hometown, so that the younger children who have migrated and the children of migrants will be familiar with its folklore and traditions.

\subsection{Formalizing solidarity: the evolution of an HTA}

One HTA, formed 15 years ago, initially sent remittances and funded the building of a water treatment system, greenhouses, and a library. Like other HTAs discussed in the previous section, this HTA recognized that its members and the broader Mexican community were struggling in NYC, and they responded. They created a health care program and then added additional services such as programs in English as a second language, health education, literacy, computer programs, and domestic violence prevention. This HTA significantly broadened its mission beyond sending remittances, so much so that its evolution necessitated that it expand its membership, leadership, and fundraising capabilities. In the last five years, it widened its funding base beyond collecting donations from individual members to applying for grants. It established an office space with paid staff members. Participants stressed that without leadership and fiscal growth the organization could not have taken on so many projects in NYC.

The primary issues that this HTA and others identified that challenged their members were immigration, education (high school or GED equivalency), job training, economic empowerment and displacement. HTA leaders repeatedly mentioned insufficient education and training as being primary barriers to their members finding higher paying jobs with more stability and benefits. Therefore, education and job training were the most frequently developed programs by HTAs. They felt that unless there is a major shift in improving access to education among the Mexican immigrant population in NYC that they would continue to struggle and occupy a precarious economic position in the informal economy. While immigration was a major concern for all HTA leaders, they were not active in providing legal services. Instead, they referred members to recommended legal service providers in the city.

Economic empowerment and displacement came up in several conversations. When asked about future goals one HTA leader said that they would like to shift focus towards advocacy and entrepreneurship in NYC. They viewed classes on financial skills (banking, managing debt and credit) and supporting immigrant entrepreneurship as building on the education and computer training services that were already offered. HTA leaders said that their members were concerned with paying taxes in the US and acquiring the financial stability to purchase property or start their own businesses in the US (and/or in Mexico). In addition, HTA leaders were troubled by the rising cost of living in NYC and witnessed their members being displaced. Their hope was that they might be able to change this trajectory and make it possible for Mexican immigrants to participate in, contribute to, and remain in neighborhoods like Bushwick and Sunset Park, Brooklyn, and even participate in city redevelopment projects.

I interpret HTA motivations for coordinating social activities and various educational programs in NYC as being rooted in solidarity practices that travel in both directions across the Mexico/US border. They are mobilizing to serve community, by sending remittances to Mexico and providing services in NYC. Activities like the soccer teams, potlucks, and donations are how HTAs practice solidarity values like mutual aid and support, and perform culture in a new place. During interviews, participants stressed that they identify with communities in Mexico and in NYC, but that these two places were not separate (Mountz and Wright, 1996). HTA members care about the lives of people in their hometown and this motivates their ethical use of collective financial resources that fund development projects. The projects that they fund solidify their relationship with the hometown. Simultaneously, they want to make a place for themselves and a name for their hometown in NYC. The projects that HTAs fund in their hometowns and the solidarity values that they exercise in NYC are not isolated from each other. They work together to build and maintain communities across borders.

\section{Conclusion}

In this article, I re-read remittances through solidarity, analyzing the ethical motivations that are behind HTA practices. HTAs do not simply defer to remittance matching programs such as $3 \times 1$. They struggle with state actors over management of the money that they raise and control of the projects that they fund. As volunteer networks, HTA members work to understand the desires of people in their hometown by engaging in transnational democratic decision-making processes. In NYC, they are dedicated to community development and use collective action to solve common problems faced by Mexican migrants. I argue that it is significant how HTAs strive to work differently than $3 \times 1$ and through their solidarity practices they distance themselves from and disrupt the dominant remittance as development discourse.

As I have shown, remittances are more than financial exchange. They are a part of complicated and changing transnational family and community relationships (Carling, 2014). This is exemplified in how the HTAs in this study carefully polled the opinions of people in NYC and the hometown and valued the perspectives of people living in the hometown, sometimes over those living in NYC. From their vantage point, it made the most sense to listen directly to people living in the hometown and carry out a project that suited their desires and not that of people living in NYC or of the Mexican government. Re-reading the 
work of HTAs through the practices of the Solidarity Economy is helpful because it troubles the assumption that collective remittances are solely economic development. Further research on the motivations, practices, and collectivity of HTAs would grow our understanding of how solidarity practices operate in and play a role in transnationalism.

Collective remittance sending to fund community infrastructure projects is just one aspect of a HTA's solidarity work. HTAs also support the Mexican immigrant population in NYC by forming volunteer networks, building organizations, and working cooperatively in the city to solve common problems that are faced by Mexican immigrants. These non-economic forms of solidarity play a vital role in local identity formation, build networks that give care, and encourage different kinds of political and social engagement. HTAs in NYC bring people together and these events help HTAs establish a name for themselves and attract others from their region. As time passes and an HTA grows its membership and becomes more established, it may broaden its focus, but remain committed to benefiting the Mexican immigrant community. HTA work is centered on providing a wide-range of community services to meet the needs of members and to propel their socio-economic position in NYC.

Finally, HTAs have a fraught relationship with $3 \times 1$. They come face to face with the critique that remittance programs channel migrant money as a substitute for government funding, and in so doing put unfair financial expectations on migrants. The participants in my research project concur with this critique, expressing that they felt used by the government to fund certain kinds of infrastructure projects in their hometowns. $3 \times 1$ has institutionalized migrant motivations for remitting, but scholars are skeptical about the policy's attempt to simply shape migrants as malleable subjects for funding economic development (Covarrubias, 2012; Delgado Wise and Rodríguez Ramírez, 2001; Pardo Montaño, 2015). On the one hand neoliberal policy processes do work to bring people under control, but on the other hand people do not easily engage in these policies and find ways to resist or challenge them (Però, 2011). The solidarity work of HTAs offers a less hierarchical, less universal and more decentralized approach to remittances as development than is typically stressed in mainstream development approaches. Furthermore, $3 \times 1$ is not a monolithic program. It is managed by three ministries of the federal government and relies on cooperation from state and municipal governments. HTAs have a wide array of complicated interactions with these state actors.

Re-reading remittances for difference and contradiction is my attempt to break out of the totalizing ideas of dominant development discourse (Escobar, 2008; Gibson-Graham, 2006). Remittances act as and are seen by migrants as more than volunteer participation in neoliberal development policies like $3 \times 1$. Central to how HTAs organize and operate are solidarity practices such as democratic decision-making processes and concern with community welfare and development. In their work building economic and non-economic solidarity across transnational spaces, HTAs are creatively adapting to, and negotiating with elements of what has been characterized as a typical neoliberal approach to development. In this work, there is potential to challenge the traditional development framework and create alternatives.

\section{Funding}

This work was supported by the New York City Chapter of the Society of Women Geographers and the Hunter College Dean of Arts and Sciences.

\section{Acknowledgements}

My deepest gratitude goes to the men and women who participated in the research that informs this paper. Thank you to the following colleagues for providing comments and criticisms that helped me write and revise this article: Harrison Cole, Lauren Hudson, Jess Linz, Dugan Meyer, Marianna Pavlovskaya, Susan Roberts, and Matthew Zook. The constructive comments of Thomas Perreault and four anonymous reviewers at Geoforum are also greatly appreciated. Any remaining errors in the paper are mine.

\section{References}

Adams Jr., R.H., Page, J., 2005. Do international migration and remittances reduce poverty in developing countries? World Dev. 33 (10), 1645-1669. http://dx.doi.org/ 10.1016/j.worlddev.2005.05.004.

Alarcón, R., Escala Rabadán, L., 2007. Transnational philanthropy and organizational strategies: the challenge of Mexican hometown associations in the United States. In: Zárate-Hoyos, G.A. (Ed.), New Perspectives on Remittances from Mexicans and Central Americans in the United States. Kassel University Press, Kassel, Germany, pp. $130-158$.

Aparicio, F.J., Meseguer, C., 2012. Collective remittances and the state: the $3 \times 1$ program in Mexican municipalities. World Dev. 40 (1), 206-222. http://dx.doi.org/10. 1016/j.worlddev.2011.05.016.

Bada, X., 2016. Collective remittances and development in rural Mexico: a view from Chicago's Mexican hometown associations. Popul. Space Place 22 (4), 343-355. http://dx.doi.org/10.1002/psp.1958.

Bakker, M., 2007. The remittances-to-development discourse and the political agency of the collective migrant. Migración Y Desarrollo 9, 45-72.

Bakker, M., 2015. Discursive representations and policy mobility: how migrant remittances became a "development tool". Glob. Netw. 15 (1), 21-42. http://dx.doi. org/10.1111/glob.12055.

Banco de México, 2017. Ingresos por Remesas: Balanza de pagos. Retrieved from. $<$ http://www.banxico.org.mx/SieInternet/consultarDirectorioInternetAction.do? accion $=$ consultarCuadro\&idCuadro $=\mathrm{CE} 81>$.

Borowiak, C., 2014. Solidarity economy as alternative economy. In: Paper presented at the Creative Alternatives to Capitalism Conference, New York, NY (May).

Brown, S.S., 2006. Can remittances spur development? A critical survey. Int. Stud. Rev. 8 (1), 55-75. http://dx.doi.org/10.1111/j.1468-2486.2006.00553.x.

Carling, J., 2014. Scripting remittances: making sense of money transfers in transnational relationships. Int. Migr. Rev. 48, S218-S262. http://dx.doi.org/10.1111/imre.12143.

Charmaz, K., 2014. Constructing Grounded Theory, second ed. SAGE Publications Ltd, London and Thousand Oaks, California.

Cloke, P.J., Cook, I., Crang, P., Goodwin, M.A., Painter, J., Philo, C.P., 2004. Practising Human Geography, first ed. SAGE Publications Ltd, London and Thousand Oaks, California.

Community Economies Collective, 2001. Imagining and enacting non-capitalist futures. Socialist Rev. 28 (3), 93-135.

Covarrubias, H.M., 2012. El Mundo Al Reves: La Migracion Como Fuente De Desarrollo. Miguel Ángel Porrúa, México, D.F.

Datta, K., McIlwaine, C., Wills, J., Evans, Y., Herbert, J., May, J., 2007. The new development finance or exploiting migrant labour? Remittance sending among low-paid migrant workers in London. Int. Dev. Plan. Rev. 29 (1), 43-67. http://dx.doi.org/10. 3828/idpr.29.1.3.

de Haas, H., 2010. Migration and development: a theoretical perspective. Int. Migr. Rev. 44 (1), 227-264.

Delgado Wise, R., 2006. Migration and imperialism: the Mexican workforce in the context of NAFTA. Latin Am. Perspect. 33 (2), 33-45.

Delgado Wise, R., Eduardo Guarnizo, L., 2007. Migration and Development: Lessons From the Mexican Experience (Migration Information Source: Fresh Thought, Authoritative Data, Global Reach). Migration Policy Institute. Retrieved from < http://s3. amazonaws.com/academia.edu.documents/30356825/migration_development lessons_mexico_raul_wise_2007.pdf?AWSAccessKeyId = AKIAJ56TQJRTWSMTNPEA\&Expires $=1462977076 \&$ Signature $=$ 42NLq2f1 db9USL6JzvsGDSVjmVU\%3D\&response-content-disposition = inline\%3B \%20filename\%3DMigration_And_Development_Lessons_From_T.pdf >

Delgado Wise, R., Rodríguez Ramírez, H., 2001. The emergence of collective migrants and their role in Mexico's local and regional development. Can. J. Dev. Stud./Revue Canadienne D'études Du Développement 22 (3), 747-764. http://dx.doi.org/10. 1080/02255189.2001.9668842.

Directorio de Organizaciones y Clubs de Oriundos, 2016. Retrieved from < http://www. ime.gob.mx/directorioorganizaciones/ $>$

Durand, J., Parrado, E.A., Massey, D.S., 1996. Migradollars and development: A reconsideration of the Mexican case. Int. Migr. Rev. 30 (2), 423-444. http://dx.doi.org/ $10.2307 / 2547388$

Elwood, S.A., Martin, D.G., 2000. "Placing" interviews: location and scales of power in qualitative research. Prof. Geographer 52 (4), 649-657. http://dx.doi.org/10.1111/ 0033-0124.00253.

Escala Rabadán, L., Bada, X., Rivera Salgado, G., 2006. Mexican migrant civic and political participation in the US: the case of hometown associations in Los Angeles and Chicago. Norteamérica 1 (2). Retrieved from < http://revistas.unam.mx/index.php/ nam/article/viewFile/15759/14969 >

Escobar, A., 2008. Territories of Difference: Place, Movements, Life, Redes. Duke University Press, Durham, NC.

Faist, T., 2008. Migrants as transnational development agents: an inquiry into the newest round of the migration-development nexus. Popul. Space Place 14 (1), 21-42. http:// dx.doi.org/10.1002/psp. 471.

Ferguson, J., 1994. The Anti-Politics Machine: "Development", Depoliticization and Bureaucratic Power in Lesotho. University of Minnesota Press, Minneapolis.

FitzGerald, D., 2009. A Nation of Emigrants: How Mexico Manages Its Migration. University of California Press. 
Fox, C., 2012. Three Worlds of Relief: Race, Immigration, and the American Welfare State from the Progressive Era to the New Deal. Princeton University Press, Princeton, N.J.

Fox, J., Bada, X., 2008. Migrant Organization and Hometown Impacts in Rural Mexico. J. Agrarian Change 8 (2-3), 435-461. http://dx.doi.org/10.1111/j.1471-0366.2008. 00176.x.

Fox, J., Bada, X., 2011. Migrant civil engagement. In: Voss, K., Bloemraad, I. (Eds.), Rallying for Immigrant Rights: The Fight for Inclusion in 21st Century America. University of California Press, Berkeley, pp. 142-160.

Gamio, M., 1930. Mexican immigration in the United States: a study of human migration and adjustment. University of Chicago Press, Chicago, IL.

Gamlen, A., 2014. The new migration-and-development pessimism. Prog. Hum. Geogr. 38 (4), 581-597. http://dx.doi.org/10.1177/0309132513512544.

García Zamora, R., 2007. El Programa Tres por Uno de remesas colectivas en México: Lecciones y desafíos. Migraciones Internacionales 4 (1), 165-172.

Gibson-Graham, J.K., 1996. The End of Capitalism (as We Knew It): A Feminist Critique of Political Economy. University of Minnesota Press, Minneapolis.

Gibson-Graham, J.K., 2006. A Postcapitalist Politics, first ed. University of Minnesota Press, Minneapolis.

Gibson-Graham, J.K., 2008. Diverse economies: performative practices for "other worlds". Prog. Hum. Geogr. 32 (5), 613-632. http://dx.doi.org/10.1177/ 0309132508090821.

Glaser, B., Strauss, A., 1967. The Discovery of Grounded Theory: Strategies for Qualitative Research. Aldine Transaction, Chicago.

Glick Schiller, N., Faist, T., 2009. Migration, development, and social transformation. Soc. Anal. 53 (3), 1-13. http://dx.doi.org/10.3167/sa.2009.530301.

Gutiérrez, A., Remington, G., 2017. What We Have Built.

Hum, T., 2014. Making a Global Immigrant Neighborhood: Brooklyn's Sunset Park Temple University Press, Philadelphia.

Iskander, N., 2010. Creative State: Forty Years of Migration and Development Policy in Morocco and Mexico. Cornell University Press, Ithaca.

Jones, R.C., 1992. U.S. migration: an alternative economic mobility ladder for rural central Mexico. Soc. Sci. Q. 73 (3), 496-510 (University of Texas Press).

Jones, R.C., 1998. Remittances and inequality: a question of migration stage and geographic scale. Econ. Geogr. 74 (1), 8-25. http://dx.doi.org/10.2307/144341.

Kanaiaupuni, S.M., Donato, K.M., 1999. Migradollars and mortality: the effects of migration on infant survival in Mexico. Demography 36 (3), 339-353. http://dx.doi. org/10.2307/2648057.

Kawano, E., 2010. Crisis and opportunity: the emerging solidarity economy movement. In: Kawano, E., Masterson, T.N., Teller-Elsbert, J. (Eds.), Solidarity Economy I: Building Alternatives for People and Planet. Center for Popular Economics, Amherst, pp. 11-24. Retrieved from < http://sduk.us/money/kawano_crisis_and_opportunity_ emerging solidarity economy movement.pdf $>$.

Loh, P., Shear, B., 2015. Solidarity economy and community development: emerging cases in three Massachusetts cities. Community Dev. 46 (3), 244-260. http://dx.doi. org/10.1080/15575330.2015.1021362.

Lopez, S.L., 2015. The Remittance Landscape: Spaces of Migration in Rural Mexico and Urban USA. University of Chicago Press, Chicago.

Massey, D.S., Parrado, E., 1994. Migradollars: The remittances and savings of Mexican migrants to the USA. Popul. Res. Policy Rev. 13 (1), 3-30. http://dx.doi.org/10. 1007/BF01074319.

Mercer, C., Page, B., Evans, M., 2008. Development and the African Diaspora: Place and the Politics of Home. Zed Books, London \& New York.

Miller, E., 2010. Solidarity economy: key concepts and Issues. In: Kawano, E., Masterson, T.N., Teller-Elsbert, J. (Eds.), Solidarity Economy I: Building Alternatives for People and Planet. Center for Popular Economics, Amherst, pp. 93-100. Retrieved from < http://www.academia.edu/download/31351729/fse.pdf\#page $=33>$.

Mountz, A., Wright, R.A., 1996. Daily life in the transnational migrant community of San Agustín, Oaxaca, and Poughkeepsie, New York. Diaspora: J. Transnatl. Stud. 5 (3), 403-428. http://dx.doi.org/10.1353/dsp.1996.0017.

Mullings, B., 1999. Insider or outsider, both or neither: some dilemmas of interviewing in a cross-cultural setting. Geoforum 30 (4), 337-350. http://dx.doi.org/10.1016/ S0016-7185(99)00025-1.

Nast, H.J., 1994. Women in the field: critical feminist methodologies and theoretical perspectives. Prof. Geographer 46 (1), 54-66. http://dx.doi.org/10.1111/j.00330124.1994.00054.x

Nelson, L., 2017. Soccer and the mundane politics of belonging: Latino immigrants, recreation, and spaces of exclusion in the rural US South. In: Koch, N. (Ed.), Critical Geographies of Sport: Space, Power and Sport in Global Perspective. Routledge, London \& New York, pp. 125-141.

Orozco, M., 2002. Globalization and migration: the impact of family remittances in Latin America. Latin Am. Politics Soc. 44 (2), 41-66. http://dx.doi.org/10.2307/3177094.

Orozco, M., 2006. Hometown associations and development: ownership, correspondence, sustainability and replicability. In: Merz, B.J. (Ed.), New Patterns for Mexico: Observations on Remittances, Philanthropic Giving, and Equitable Development.
Nuevas Pautas para México: Observaciones sobre Ellipsis Equitativo, Bilingual ed. Global Equity Initiative, Harvard University, Cambridge.

Orozco, M., Rouse, R., 2007. Migrant hometown associations and opportunities for development: a global perspective. (February 1 ). Retrieved from $<$ http://www. migrationpolicy.org/article/migrant-hometown-associations-and-opportunitiesdevelopment-global-perspective $>$ (November 16, 2016).

Pardo Montaño, A.M., 2015. Migración internacional y desarrollo. Aportes desde el transnacionalismo. Revista de Estudios Sociales 54, 39-51. http://dx.doi.org/10 7440/res54.2015.03.

Pavlovskaya, M., 2013. Between neoliberalism and difference: multiple practices of property in post-Soviet Russia. Europe-Asia Stud. 65 (7), 1295-1323. http://dx.doi. org/10.1080/09668136.2013.822708.

Però, D., 2011. Subjects of policy: construction and contestation. In: Shore, C., Wright, S. Però, D. (Eds.), Policy Worlds: Anthropology and the Analysis of Contemporary Power. Berghahn Books, New York.

Price, M., Whitworth, C., 2004. Soccer and latino cultural space: metropolitan Washington Fútbol leagues. In: Arreola, D.D. (Ed.), Hispanic Spaces, Latino Places: Community and Cultural Diversity in Contemporary America. University of Texas Press, Austin, pp. 167-186.

Ramakrishnan, S.K., Viramontes, C., 2010. Civic spaces: Mexican hometown associations and immigrant participation. J. Soc. Issues 66 (1), 155-173. http://dx.doi.org/10. 1111/j.1540-4560.2009.01638.x.

Ratha, D., 2003. Workers' Remittances: An Important and Stable Source of External Development Finance. World Bank. Retrieved from < http://repository.stcloudstate. edu/cgi/viewcontent. cgi ?article $=1009 \&$ context $=$ econ seminars $>$.

Ratha, D., 2005. Workers' remittances: an important and stable source of external development finance. Retrieved from. < http://repository.stcloudstate.edu/cgi/ viewcontent. cgi article $=1009 \&$ context $=$ econ seminars $>$.

Ratha, D., 2006. Leveraging Remittances for Development (Migration, Trade, and Development). Retrieved from. < http://web1.dallasfed.org/assets/documents/ research/pubs/migration/migration.pdf \# page $=171>$.

Ratha, D., 2007. Leveraging remittances for development. In: Hollifield, J.F., Orrenius, P.M., Osang, T. (Eds.), Migration, Trade, and Development: Proceedings of a Conference. Federal Reserve Bank of Dallas, Dallas, pp. 173-186.

Ratha, D., Eigen-Zucchi, C., Plaza, S., 2016. Migration and Remittances Factbook 2016, third ed. World Bank Publications.

Rivera, A., 2003. The Sixth Section. Second Generation Media.

Russell, S.S., 1986. Remittances from international migration: a review in perspective. World Dev. 14 (6), 677-696. http://dx.doi.org/10.1016/0305-750X(86)90012-4.

Safri, M., Graham, J., 2010. The global household: toward a feminist postcapitalist in ternational political economy. Signs 36 (1), 99-125. http://dx.doi.org/10.1086/ 652913.

Santos, B.D.S., Rodríguez-Garavito, 2007. Introduction: expanding the economic canon and searching for alternatives to neoliberal globalization. In: Santos, B.D.S. (Ed.), Another Production is Possible: Beyond the Capitalist Canon, first ed. Verso, London \& New York.

SEDESOL: Secretaría de Desarrollo Social, 2015. Personal Communication (April 2).

Smith, M.P., Bakker, M., 2007. Citizenship across Borders: The Political Transnationalism of El Migrante. Cornell University Press, Ithaca. Retrieved from < https://muse.jhu. edu/book/24606 >

Smith, R.C., 2001. Mexicans: Problems and Prospects in New York. In: Foner, N. (Ed.), New Immigrants in New York, completely revised and updated edition. Columbia University Press, New York, pp. 275-300.

Smith, R.C., 2006. Mexican New York: Transnational Lives of New Immigrants. University of California Press, Berkeley. Retrieved from < http://www.ucpress.edu/book.php? isbn $=9780520244139>$.

The Associated Press, 2017. Mexico's Remittances Reach Almost \$27 Billion. The New York Times. (February 1). Retrieved from $<$ https://www.nytimes.com/aponline/ 2017/02/01/world/americas/ap-lt-mexico-remittances.html > .

Vonderlack-Navarro, R., Sites, W., 2015. The bi-national road to immigrant rights mobilization: states, social movements and Chicago's Mexican hometown associations. Ethnic Racial Stud. 38 (1), 141-157. http://dx.doi.org/10.1080/01419870.2013. 809128.

Waldinger, R., Popkin, E., Magana, H.A., 2008. Conflict and contestation in the crossborder community: hometown associations reassessed. Ethnic Racial Stud. 31 (5), 843-870. http://dx.doi.org/10.1080/01419870701491929.

Zabin, C., Escala Rabadán, L., 2002. Mexican hometown associations and Mexican political empowerment in Los Angeles. Frontera Norte 14 (27), 7-42.

Zapata, G.P., 2013. The migration-development nexus: rendering migrants as transnational financial subjects through housing. Geoforum 47, 93-102. http://dx.doi.org/ 10.1016/j.geoforum.2013.03.010.

Zarate-Hoyos, G.A., 2004. Consumption and remittances in migrant households: toward a productive use of remittances. Contemp. Econ. Policy 22 (4), 555-565. http://dx.doi. org/10.1093/cep/byh042. 